\title{
Study of Literary Images of Gifted Characters In Optional Activities As a Means to Develop Capable and Talented Youth
}

Galina Nikolaevna Bozhkova, ${ }^{\dagger}$ Elena Mikhailovna Shastina, ${ }^{\dagger}$ Olga Valerevna Kalimullina, ${ }^{\dagger *}$ and Olga Vasilyevna Shatunova ${ }^{\dagger}$

\section{Abstract}

The studies of the life and work of the writers of the second half of the 19th Century, such as N.S. Leskov and F.M. Dostoevsky allow considering the problem of giftedness in the literary aspect. The authors of the article identify the characters' inborn, professional and acquired giftedness in the reviewed literary works, and consider features of the images of the gifted characters. The practical significance of the study is in providing teachers with methods of work during elective classes on studying the problem of giftedness. The results of the authors' experimental work prove that this form of studies contributes to the development of schoolchildren's interest in literature, and stimulates their research activities.

Keywords: Giftedness, Types of Giftedness, Classical Literature, Elective Classes, Literary Talent

\footnotetext{
${ }^{+}$Kazan (Volga Region) Federal University. 89, Kazanskaya Street, Elabuga, Tatarstan, 423602

' The Bonch-Bruevich St. Petersburg State University of Telecommunications. 22, av. Bolshevikov, block 1, St.

Petersburg, Russia, 193232

*Corresponding Author, Email: chemireva@mail.ru

(C) 2019 Bozhkova et al. This is an Open Access article distributed under the terms of the Creative Commons Attribution License (http://creativecommons.org/licenses/by/2.0), which permits unrestricted use, distribution, and reproduction in any medium, provided the original work is properly cited.
} 


\section{Introduction}

The purpose of the article is to identify the typical traits of gifted characters in classic works of the 19th Century literature and confirm that such work in elective classes contributes to the development of teenagers' literary talent.

The novelty of the research lies in the fact that the article presents a comprehensive analysis of the characters in the works of classics from the problem of talent, which has previously been discussed only in the framework of philosophy, psychology, and pedagogy. Despite numerous publications, there is not a single study that considers the influence of images of literary heroes with signs of giftedness on the development of the literary talent of students outside school hours.

The emergence of genuine interest in the concept of "genius" is associated with the emergence on the creative scene of great scientists, artists, writers, sculptors and architects, including Leonardo da Vinci, Michelangelo Buonarroti, M. Montaigne, E. Rotterdam, N. Copernicus, N. Machiavelli, D. Alighieri, F. Petrarch, W. Shakespeare. The concept of genius begins to change with the advent of the Enlightenment (the 17th - 18th Centuries). Scientists and philosophers of the time, such as D. Locke, F. Hutcheson, C. Helvetius, D. Diderot, doubted that genius had a divine origin. They argue that all people are born with the same abilities and only under the influence of life circumstances become different. In the era of romanticism, genius and talent are defined as the "national spirit", character of the nation or epoch. The German philosopher and enlightener F. Hegel was the first to discuss the phenomenon (Leites, 2003).

The next step in the development of ideas about genius was the development of the idea of intellectual giftedness. The methodology of A. Binet has been widely used as a means of determining giftedness and identifying gifted children.

The well-known Soviet psychologist and philosopher S.L. Rubinstein was engaged in the development of this problem. In the book "Fundamentals of General Psychology", he identifies general talent as a combination of all qualities of a person, on which productivity depends, and special abilities that help an individual to perform a particular activity better than others (Rubinstein, 2009: 513).

The study of talent is still relevant at present. A whole galaxy of scientists, relying on the centuries-old experience of psychologists, teachers, philosophers, do bring not only new definitions of talent, a genius but also systematise knowledge, highlighting the signs and types of talent.

In Russia, most researchers today regard giftedness as "the systemic quality of the psyche that develops throughout life, which determines whether a person can achieve higher results in one or several activities as compared to other people" (Panyutina, 2008: 4). M. Handel, W. Vialle, A. Ziegler confirm the findings. They have conducted an extensive survey involving 1,469 schoolchildren of private and public schools and are convinced that gifted pupils have higher academic self-efficacy than their peers (Handel, 2013: 99-114). H.J. Boor-Klip, A.H. Cillessen \& J.G. Hell have conducted a survey that involved 671 schoolchildren that proves that pupils with high abilities are better adapted socially than their peers who show no signs of giftedness (Boor-Klip et al., 2014: 259271).

B.M. Teplov, a well-known researcher of the phenomenon, wrote that "giftedness is a qualitatively peculiar combination of abilities, on which the possibility of achieving greater or lesser success in the performance of a particular activity depends" (Teplov, 1982: 136). It follows from this definition that giftedness does not guarantee success in any activity, but only provides "building material" for its achievement.

Panyutina speaks about the signs of giftedness, among which are: the individual's specific activity strategies, the fully formed, qualitatively new, individual style of activity, a special type of organisation of knowledge, high demands on the 
results of one's work. The following types of giftedness are identified: intellectual, artistic and aesthetic, spiritual value, talent in practical activities (Panyutina, 2008). This classification will be used in our analysis of literary works.

Albert Ziegler emphasises that giftedness is, above all, a person's ability to achieve excellence in any field of art, profession or science. However, in order to develop giftedness, it is necessary to improve it and learn effectively. If a gifted child does not develop his abilities, he will not be able to achieve outstanding results (Händel et al., 2013; Ziegler, 2018). German researchers propose the giftedness model "Actiotope", according to which a gifted child is to be included in a developing environment that will contribute to the development of his abilities. A gifted child will develop only in case of dynamic interaction with the developing environment. Today, it seems not enough to have enriched and accelerated development programmes, it is necessary to develop a mentoring system and e-learning programmes for gifted children. The Czech scientists J. Mudrak and K. Zabrodska (Mudrak and Zabrodska, 2015) claim that many parents and teachers have no idea how to work with children in order to develop their talents. F. Preckel, T Gotz. (Preckel et al., 2010), engaged in the problem, observe that it is a frequent case that boys showing high academic performance are given disdainful nicknames, which confirms the wrong approach to teacher education (Preckel et al., 2010); they are often called gay because of low masculinity, and gifted girls are ignored by their peers (Olthouse, 2014).

Scholars testify the necessity of specially designed teacher training programmes aimed at the development of gifted children (Troxclair, 2013). R. Subotnik, P. Olszewski-Kubilius believe that for the successful development of personal talent and its implementation in society, what is necessary is not only a high level of development of certain abilities, but also such personal qualities as willingness to take on strategic risks, an ability to cope with environmental challenges and hazards, an ability to criticise and positively relate to constructive criticism, competitiveness in the labour market, and high cognitive motivation and purposefulness (Subotnik et al., 2011).

The American educator Dorothy Sisk (Sisk, 2008) draws attention to the emotional component of children's giftedness. She believes that a discussion of life values with reputable people will help to remove irritation and a sense of social injustice. T. Baudson, F. Preckel in the article "Teachers' Implicit Personality Theories about the Gifted: An Experimental Approach" express a belief that teachers can be those reputable people, and the interaction of gifted adolescents with teachers will contribute both to an increase in the teacher's rating and to the destruction of the learners' "disharmony hypothesis" (Baudson and Preckel, 2013: 37-46).

Particular attention is given in the article "Parenting Gifted Children among Hong Kong Chinese Parents: What Differences Does Westernization Make?" by D.W. Chan to the socio-psychological aspect of training gifted children in acceleration programmes and special classes. The results of research in the following areas are considered: ordinary schoolchildren' and teachers' ideas about gifted children; peers', classmates', parents', teachers', and gifted children's attitudes to pupils with high abilities (Chan et al., 2013: 177-186.). D.Y. Dai and S. Steenbergen-Hu in the article "Special Class for the Gifted Young: A 34-Year Experimentation with Early College Entrance Programmes in China" offers a programme of early talent development using the example of the Chinese College of Mathematics, describes the features of admission to the educational institution, the syllabus and the level of school leavers, arguing that such colleges work for the good of the society, and offers to learn from the Chinese colleagues (Dai and Steenbergen$\mathrm{Hu}, 2015:$ 9-18).

Against the backdrop of the theoretical understanding of the subject and the degree of knowledge of the topic, this research aims to probe the literary images of gifted characters in optional activities as a means to develop capable and talented youth. Next section discusses the 
methods applied for this research. It describes the techniques and means by which the stated goal was achieved. The results and analysis are outlined in the section following the methods section. Finally, the Conclusion section reflects a reasoning process, during which a transition from some initial judgments to an assertion is made.

\section{Methods}

The following methods based in general on the principles of various branches of science are used:

- theoretical research methods: analysis of philosophical, psychological, sociological, pedagogical literature on the research topic, as well as literary works of the Russian classics; synthesis for the study of advanced psycho-pedagogical and philosophical experience in the examination of giftedness, acquisition of a comprehensive view of the development of giftedness in the world and a complete picture of the process under study; abstraction when studying the influence of detailed work with images of gifted characters in optional classes on the development of creatively gifted young people - they all allow clarifying conceptual concepts, expanding and systematising scientific facts, explaining and predicting phenomena, increasing the reliability of the empirical results, moving from abstract knowledge to specific;

- relying on cultural-historical (when interpreting works of art), socio-cultural (when considering giftedness on a broader perspective, using the literary context), typological approaches, it is possible to state the typological commonality of literary characters endowed with signs of giftedness;

- empirical methods: specially designed questionnaires, content analysis, analytical conversation, experiment. This group of methods is aimed at clarifying the understanding of the word 'giftedness' by schoolchildren, students and teachers, their knowledge of the features of a gifted person, and allows noticing the positive impact of studying literary characters with signs of giftedness on the development of adolescent talent.

The experimental base of research was Elabuga Institute of Kazan Federal University and secondary school No. 3 (Elabuga). A survey involving schoolchildren and teachers aged from 16 to 56 was conducted in 2018. The study covered a total of 244 people.

\section{Research Stages Research}

- the study of philosophical, psychological, sociological, pedagogical literature, trends in the theory and practice of teaching gifted children;

- theoretical and experimental work on the study of school and literary talent as a pedagogical phenomenon;

- development and organisation of elective classes on the study of the types of gifted literary characters on the example of the classical literature of the $19^{\text {th }}$ century. Implementation of the results in practice;

- experimental verification of the developed theoretical positions. Systematisation and generalisation of the results.

\section{Results}

As a result of the survey, we obtained the following data: for $72.4 \%$ (165 people) of respondents, giftedness is "the person's endowment by any abilities (mental, spiritual, musical, artistic ...), a combination of individual qualities, personality traits". $14.5 \%$ (33 people) of the respondents are convinced that giftedness should be understood as "having some talent / the same as talent"; $6.6 \%$ (15 people) associate giftedness with the term "mindset/set of intellectually developed traits/extraordinary thinking"; $2.6 \%$ (6 people) think that giftedness is "the result of man's work on himself". The same number of respondents (6 people) is convinced that giftedness is "a deposit of 
genius"; $1.3 \%$ (3 people) calls it "the highest degree of spiritual development".

Therefore, we may conclude that in everyday life giftedness is most often understood as having any general abilities (musical, mental, spiritual). This understanding does not disagree with the ideas of psychologists.

As a part of the study, we conducted elective classes with a group of $10^{\text {th }}$ form pupils on the topic: "What do we know about giftedness? Characters with signs of talent in the literature of the second half of the 19th Century (on the example of the works by Dostoevsky, Leskov)". Special tasks have been developed for the class that study in detail the images of literary heroes with features of giftedness in curriculum works since the lessons most often focus on the literary work ideological and thematic aspects.

The first part of the lesson was a questionnaire; the pupils working in pairs were asked to respond to three questions: "What is talent, in your opinion?"; "What qualities should a gifted person have?"; "Do you consider yourself gifted?"

The pupils had to answer the last question twice - at the beginning of the first lesson, before studying a gifted character in literary works and at the last lesson.

An analytical conversation, following the questioning, and elective classes with 16 schoolchildren of the $10^{\text {th }}$ form allowed obtaining an exciting result: $62 \%$ of schoolchildren do not consider themselves gifted at the beginning of the first class (10 pupils out of 16); while at the last class, after learning some types of talents and characters of the Russian classical literature with signs of giftedness, their opinions have changed - only $38 \%$ of the respondents do not call themselves gifted. The pupils supported their assertions in different ways: an ability to play musical instruments, an outstanding skill of reciting poems (the winner's diplomas serve as evidence), academic success, possession of such qualities as kindness and purposefulness necessary for productive activity in the volunteer movement. Completing the lesson, the pupils knew the types of N.S. Leskov's and F.M. Dostoevsky's gifted characters, but also found talents of their own, admitting that they wanted to continue working with gifted characters of both classical and modern prose, and also planned to develop their talents.

\section{Discussion}

In the 21st Century, professional and personal training of teachers to work with gifted children is conducted; new methods and techniques are emerging. Schools and kindergartens, as the most critical social organisations, are actively introducing methods for diagnosing talent, conducting optional classes designed to give impetus to the development of the phenomenon of child and adolescent talent; scientists are actively developing models of giftedness, which are designed to explain this phenomenon and help teachers in developing approaches to teaching gifted children. The interest of teachers in the concept of J. Renzulli (Renzulli, 1994) is because, under it, a more significant number of children can be classified as gifted. Thus, the scientist does not associate the concept of "giftedness" ("potential") with high rates for each parameter; in his opinion, the category of gifted can be attributed to those who showed excellent results in at least one of the parameters.

Here, we propose to develop the necessary and motivational components of giftedness in elective literature classes using studying the literary images of characters endowed with signs of giftedness, for Russian writers have invisibly joined the discussion of giftedness. Although there is not a single article about gifted characters in Russian prose, one cannot deny their influence on the development of schoolchildren's giftedness. To illustrate it, we turned to Russian literature at the end of the 19th Century and studied some works included in the school curriculum to find characters with signs of talent.

Nikolai Semenovich Leskov is known for his portrayal of the life of a Russian: "Inspired by a great love for his people, he sought to encourage and inspire Russia" (Leskov, 1989). In his works, he reflected the people's feats. The writer 
portrayed "common people" as not only hardworking but also wise. Leskov, with his keen interest in the national culture, managed to create an amazing artistic world of the life of talented and creatively gifted people.

Analysing Leskov's works, we came to the conclusion that the main characters are similar: they are talented; in our study we designated this feature with the term "professional talent", based on the definition of S.L. Rubinstein that "professional giftedness is the totality of all human qualities on which the productivity of his activity depends" (Rubinstein, 2009: 540).

Thus, professional giftedness or talent is a type of giftedness that is characterised by a high level of professional activity performance with the introduction of original, qualitatively new ideas and solutions, and the one that includes the innate abilities of the individual. The latter in the structure of professional giftedness, in our opinion, is attentiveness, composure, readiness for hard and long work. These properties, no doubt, are typical of the main character of the story "Lefty" by N.S. Leskov.

An essential feature of the professionally gifted character in work is his imagination and ingenuity. The idea to shoe a flea is original in itself and so unexpected that no one could have guessed exactly what changes it would involve. It is not by chance that in the story on the crosseyed left-hander, there is a phrase "Something special has been done here" (Leskov, 1989: 220) - this is what Tsar Nikolai Pavlovich says, looking at the flea. The fact is that the diligent and patient Tula masters not only shod an English flea, but forged their names on each flee shoe. However, even here the author emphasies Lefty's unique position: his name is not indicated on the flee shoes, for he has forged the nails with which the flee shoes are hammered.

The protagonist of the work "The Toupee Artist" - Arkady - is also professionally gifted. Describing the character, Leskov often speaks about his main feature: "... he was not a simple, trivial coiffeur, a barber with a hairbrush behind his ear; he was a person with ideas - in a word, an artist" (Leskov, 1989: 91). It is in the obsession with the idea that the author distinguishes the difference of the main character from all other barbers, for he could turn any ugly person into a handsome man.

Like all professionally gifted characters created by Leskov, Arkady had an unsurpassed skill. "No one could have made an ugly face more beautiful than he" (Leskov, 1989: 91), the character of the story Lyubov Onisimovna told about him. The coiffeur Arkady could be so deeply indulged into his work that for some time, he could be in "creative oblivion" (Leskov, 1989: 92). Maximum focus on the subject of work gave him creative inspiration.

Professional talent is not related to heredity, it is the result of continuous conscious work on oneself, bringing one's skills to perfection, and most often, this skill was acquired in early childhood (Bogoiavlenscaia, 2003). The statement helps to reveal the image of the protagonist of the work "Patcher". Vasily Konych "from childhood had a special talent - to sew up" - the skill that he was continuously developing throughout his life.

An important feature of the gifted characters created by Leskov is respect for themselves and their work. They are ready to respond without servility, with dignity to anyone who treats their work unfairly. So, the Tula master Lefty, replies fearlessly to the Cossack Platov's insulting words: "You should not have offended us .. now we will not tell you the secret of our work..." (Leskov, 1989: 238). Vasily Konych is unwilling to carry the dress coat that he has mended to the visiting gentleman because he "didn't like the way he was treated" (Leskov, 1989: 99).

Gifted characters in Leskov's works differ from the rest not only in their abilities and inherent qualities but also in their external features. There is a defect in Lefty's appearance - the character is cross-eyed, squint or his face is skewed somehow on one side, but despite it, he is an inimitable master. This deficiency is most likely to help him. It is no accident that it is he who forges the smallest spare parts. Toupee artist Arkady, on the contrary, was very handsome. The creative nature was transparently guessed in his outstanding 
appearance. For the tailor Vasily Konych, appearance is not the main indicator, his work being his primary trait.

All the above allows concluding that the professional talent of the characters combines two components: intellectual and creative.

F.M. Dostoevsky (1991) depicts gifted people in his numerous works (Holondovich, 2012). In this paper, we focus on the artistic techniques that convey the psychological characteristics of the two gifted characters in his novel "The Brothers Karamazov" - the old man Zosima and Aleksey Fyodorovich Karamazov.

Aleksey Karamazov is the phenomenon of the whole work. The uniqueness of his image is apparent. He is a link between worldly life and monastic life, a point of contact between elder brothers, a bond between the father, Fyodor Pavlovich and Aleksey's brother Dmitry. His image is exceptionally harmonious, possessing persistent convictions, being kind and purehearted, having an open heart, despite internal contradictions. These qualities distinguish the character from all others. He has been silent, thoughtful, unsociable, rarely frisky, or cheerful since childhood. Dostoevsky highlights his curiosity that manifests itself first in the love of reading books and later in the desire to know human souls. He inherited from his mother the qualities that distinguish him from many other characters of the novel - love and attention to people, faith, and care for them. In this kind of philanthropy, there is a particular childishness of Alexei himself, which, of course, is also a sign of the character's talent, which differs from those around him even in external features: Aleksey is a handsome, red-cheeked, bright-eyed teenager, very handsome, of medium height, dark auburn, with shining eyes wide apart. As we can see, the character has not only internal beauty and harmony, but also external - his appearance is somewhat iconic. It is obvious that there existed certain predestination in Aleksey's fate and life. He finds in the monastery not only peace of mind but also a teacher, a senior mentor, a man who had a significant influence on his worldview and all his life - the old man Zosima.
Zosima's ability to understand and feel the souls of people allowed him to do extraordinary things. He gave people faith: in God, right, and what is most important, in themselves. It is noteworthy that gifted people have a keen sense of humour. Aleksey Karamazov was surprised at the old man Zosima's ability to look at everything that was happening with a smile. He was almost always cheerful in speaking to people. Zosima's talent can be classified as acquired (Teplov, 1982; Rubinstein, 2009), for it was manifested long after birth. Dostoevsky writes that the old man in his youth was a military man and served in the Caucasus in the rank of the chief officer. Zosima gaining himself and his true vocation is described in detail in the biographical information from the life of the old man. During the years of service in the holy place, the old man developed a unique ability to guess at first glance at the face of the stranger the reason that brought him there. Many people called it the gift of foresight; meanwhile, it is only the wisdom of the old man's vision, not available; however, to everyone. The highest degree of Zosima's wisdom manifestation is that anticipating the future suffering of Dmitry Fyodorovich Karamazov, he, kneeling, bowed to his feet. The profound wisdom and knowledge of life lie in the teachings of the old man Zosima.

Summarising it, we can conclude that Aleksey Karamazov and the old man Zosima are gifted personalities. Aleksey possesses an innate, or natural, talent, which is hereditary, its first signs having been manifested in childhood. Zosima's talent can be considered an acquired one, for it is the wisdom of life, the result of tremendous spiritual work on his own perfection. The portrait characteristics, the characters' reasoning, and their biographical data help the reader to see and understand their uniqueness and originality.

In the conditions of rapidly developing technologies, the emergence of many modern professions that require the use of qualitatively new competencies, there is a need to educate a person who is able to adapt to the changing conditions of the social environment quickly, as well as to develop gifted children who are ready not only to change themselves, but also to 
change society, creating something qualitatively new. In accordance with this, new forms and methods of working with children are being developed, relations between subjects of education (pupil - teacher) are moving to a different level. In accordance with the purpose of the article, we propose to use the method of horizontal enrichment for the development of gifted adolescents, complementing the traditional curriculum with optional classes in which students could study the types of gifted literary heroes in classical prose. For example, we analysed the gifted heroes in the works of Leskov and Dostoevsky and revealed the presence of such types of gifted characters as congenital, natural and acquired - this material was used at elective classes. Questioning and analytical conversation confirmed the effectiveness of the lessons: studying various types of gifted literary characters develops curiosity, hypersensitivity, cognitive independence, increased interest in divergent tasks, flexibility and originality of thinking, which contribute to the development of literary talent that includes impressionability, ease of creative state, richness of verbal associations, and sense of language. The experiment conducted by us in extramural hours, involving pupils of the 10th form of the secondary school, proves that many participants note a feeling of being gifted, realising that they have created a new "cultural product", making it easy and interesting for them to enter the process of mastering the imaginative system and find something unexplored in it. It is obvious that the years of learning are replaced by years of mastery, though not for everyone.

\section{Conclusion}

Central to the research was to identify the typical traits of gifted characters in classic works of the 19th Century literature and confirm that such work in elective classes contributes to the development of teenagers' literary talent. By studying the talent of literary characters, children learn to understand the psychology of not only people but literary characters and understand works of art, as well as analyse themselves. This requires experience, so people with literary talent manifest themselves much later (Leites, 2003). To be literarily gifted does not mean writing literary works (although many of the pupils wrote or started to write, the schoolchildren respondents admitted that they "took up the pen"), it means mastering the language of artistic images. This type of talent very rarely develops on its own, it needs a mentor, as a rule, it is a teacher who must choose the function of "mentor" and help the gifted pupils to master the literary field, to discover their own style. In modern conditions, not every teacher can become a "mentor", so it is worth changing the focus from giftedness to the personality of the gifted pupil, from the process of developing certain qualities to the process of pedagogical support.

\section{References}

Baudson, T. G., \& Preckel, F. (2013). Teachers' implicit personality theories about the gifted: An experimental approach. School Psychology Quarterly, 28(1), 37-46. doi:10.1037/spq0000011

Boor-Klip, H. J., Cillessen, A. H. N., \& van Hell, J. G. (2014). Social understanding of highability children in middle and late childhood. Gifted Child Quarterly, 58(4), 259-271. doi:10.1177/0016986214547634

Chan, D. W., Chan, L., \& Chanannette, C. (2013). Parenting gifted children among hong kong chinese parents: What differences does westernization make? Roeper Review, 35(3), 177-186. doi:10.1080/02783193.2013.794891

Dai, D. Y., \& Steenbergen-Hu, S. (2015). Special class for the gifted young: A 34-year experimentation with early college entrance programs in china. Roeper Review, 37(1), 918. doi:10.1080/02783193.2014.975882

Dostoevsky, F.M. (1991). Collected Works in Fifteen Volumes. Leningrad: Science. 696 p.

Händel, M., Vialle, W., \& Ziegler, A. (2013). Student perceptions of high-achieving classmates. High Ability Studies, 24(2), 99114. doi:10.1080/13598139.2013.843139 
Holondovich, E.N. (2012). The personality of a genius (a study performed on the example of studying the life path and works of FM Dostoevsky). In the collection: The Modern

Personality: Psychological Studies. Ser. "Proceedings of the Institute of Psychology RAN". Institute of Psychology RAN. Moscow.

Leskov, N.S. (1989). Story and stories. Ufa: Bashkir book publishing house. $432 \mathrm{p}$.

Leites, N.S. (2003). What does a "gifted child" mean? Art at school. No. 3.

Mudrak, J., \& Zabrodska, K. (2015). Childhood giftedness, adolescent agency: A systemic multiple-case study. Gifted Child Quarterly, 59(1), 55-70. doi:10.1177/0016986214559602

Olthouse, J. (2014). How do preservice teachers conceptualize giftedness? A metaphor analysis. Roeper Review, 36(2), 122-132. doi:10.1080/02783193.2014.884200

Panyutina, N.I. (2008). The system of work of an educational institution with gifted children. $2^{\text {nd }}$ edition, stereotypical. Volgograd: Teacher Publishing House, 2008. 204 p.

Preckel, F., Gotz, T., \& Frenzel, A. (2010). Ability grouping of gifted students: Effects on academic self-concept and boredom. British Journal of Educational Psychology, 80(3), 451-472. doi:10.1348/000709909X480716

Renzulli, J.S. (1994). Schools for talent development: A practical plan for total school improvement. Mansfield Center, CT: Creative Learning Press

Rubinstein, S.L. (2009). Basics of general psychology. St. Pererburg: Peter. 713 p.

Sisk, D. (2008). Collaborative Literacy: Using Gifted Strategies to Enrich Learning for Every

Student_Softcover, Corwin. 340 p.

Subotnik, R.; Olszewski-Kubilius, P. \& Frank, C. (2011). Worrell Rethinking Giftedness and Gifted

Education: A Proposed Direction Forward Based on Psychological Science. Psychological Science in the Public Interest. 12(1).
Teplov, B.M. (1982). The Abilities and giftedness, Psychology of individual differences. Texts Moscow: Moscow State University Publishing House. 404 p.

Troxclair, D. A. (2013). Preservice teacher attitudes toward giftedness. Roeper Review, 35(1), 58-64. doi:10.1080/02783193.2013.740603

Ziegler, A.; Balestrini, D. \& Stoeger, H. (2018). An International View on Gifted Education: Incorporating the Macro-Systemic Perspective. In: Pfeiffer S. (eds). Handbook of Giftedness in Children. Springer, Cham.

\section{Acknowledgements}

We want to thank anonymous reviewers for their comments and recommendations. The work is performed according to the Russian Government Program of Competitive Growth of Kazan Federal University. This research is supported by RFBR (grant 16-2912965\18).

\section{About the Authors}

Dr Bozhkova Galina Nikolayevna is an Associate Professor in Philology, Kazan Federal University, Yelabuga Institute, Russian Federation, Department of German Philology. Her research interests are literary studies, history of Russian literature of the nineteenth century, children's literature, regional literature, literary pedagogy (orcid.org/0000-0001-7204-1504).

Professor Shastina Elena Mikhailovna is Head of Department of German Philology, Kazan Federal University, Yelabuga Institute, Russian Federation, Department of German Philology, Her research interests are the literature of German-speaking countries, the literature of peoples of foreign countries, theoretical foundations of multilingual education, the language of mass media (orcid.org/0000-00019551-5469).

Dr Kalimullina Olga Valeryevna is an Associate Professor in Economics, The Bonch-Bruevich Saint-Petersburg State University of Telecommunications, S-Petersburg, Russian Federation, Department of Management and Modeling in Socio-Economic Systems. Her research interests are digital educational tools, 
online educational platforms, innovations, Korableva O., Durand T., Kalimullina O., knowledge management, innovative Stepanova I. (2019). Studying user satisfaction development, knowledge model with the MOOC platform interfaces using the (orcid.org/0000-0002-7782-6148).

example of Coursera and Open Education

Dr Shatunova Olga Vasilyevna is an Associate Professor and Head of the Department of Education, Kazan Federal University, Yelabuga Institute, Russian Federation, Department of Education. Her research interests are art pedagogy, literary pedagogy, gaming technology in education, information technology in social work.

Some of the authors' latest publications include:

Boshkova, G., Shastina, E., \& Shatunova, O. (2018). The role of grandparents in the child's personality formation (on the material of children's literature). Journal of Social Studies Education Research, 9(2), 283-294. doi:10.17499/jsser.14474 platforms. Proceedings of the International Conference on Big Data and Education (ICBDE 2019). University of Greenwich, London, UK, March 30-April 01, 2019. (in press)

Shastina, E., Shatunova, O., Borodina, T., Borisov, A., \& Maliy, Y. (2018). The role of reading in the development of giftedness in the context of globalization and national identity. Journal of Social Studies Education Research, 9(1), 158-167. doi:10.17499/jsser.97204

Shastina, E., Shatunova, O., Bozhkova, G., Bykov, A., \& Trofimova, L. (2019). Family reading in children literacy skills formation. [Çocuk okuryazarlığı becerileri formasyonunda aile okuma] Elementary Education Online, 18(1), 296-306. doi:10.17051/ilkonline.2019.527224 